\title{
Contributing factors and variability of energy expenditure in non-obese, obese, and post-obese adolescents
}

\author{
Michel VERMOREL ${ }^{a *}$, Stefano LAZZER ${ }^{\mathrm{b}}$, Abdelali BITAR ${ }^{\mathrm{c}}$, \\ Jérôme RIBEYRE ${ }^{\mathrm{d}}$, Christophe MONTAURIER ${ }^{\mathrm{b}}$, Nicole FELLMANN ${ }^{\mathrm{d}}$, \\ Jean COUDERT ${ }^{\mathrm{d}}$, Martine MEYER $^{\mathrm{e}}$, Yves BOIRIE $^{\mathrm{b}}$ \\ a Energy and Lipid Metabolism Research Unit, INRA, Theix, 63122 St-Genès-Champanelle, France \\ b Energy and Protein Metabolism Research Unit, INRA, University of Auvergne, CRNH, \\ 63001 Clermont-Ferrand, France \\ c Department of Biology, Applied Physiology Laboratory, Faculty of Sciences, El Jadida, Morocco \\ d Physiology and Sports Biology Laboratory, Medical Faculty, 63001 Clermont-Ferrand, France \\ ${ }^{\mathrm{e}}$ Hôtel-Dieu Pediatric Hospital, Human Nutrition Research Centre in Auvergne, \\ 63001 Clermont-Ferrand, France
}

(Received 9 August 2004; accepted 5 January 2005)

\begin{abstract}
Energy expenditure (EE) is a major determinant of energy balance and body composition. The objectives of this paper were to review the contributing factors of the main components of daily $\mathrm{EE}$ (DEE) and the inter-individual variability in these components in non-obese (NOb), obese (Ob), and post-obese (POb) adolescents. Body composition especially fat-free mass (FFM), is the major determinant of the basal metabolic rate which contributes 50-70\% of DEE, whereas fat mass (FM) is a significant factor only in obese subjects. Physical activity is the second main variation factor of DEE, whereas growth, the thermic effect of food, and thermoregulation are generally of marginal importance. The energy costs and EE associated with various sedentary and physical activities were assessed in $\mathrm{NOb}, \mathrm{Ob}$ and $\mathrm{POb}$ subjects both in standardised and in free-living conditions. The interindividual variability of DEE is high, even after adjustment for body composition, mainly because of great differences in time devoted to the various physical activities. DEE and EE associated with sleep and sedentary activities are significantly higher in $\mathrm{Ob}$ than in NOb, but not after adjustment for FFM. On the contrary, EE associated with physical activities is not significantly different between $\mathrm{Ob}$ and $\mathrm{NOb}$ adolescents, but $61 \%$ lower in $\mathrm{Ob}$ subjects after adjustment for body composition. Multidisciplinary weight-reduction programmes including moderate energy restriction and physical training result in great FM loss, maintenance of FFM, improvement of physical capacities, but reductions in organ and tissue metabolic rate and in EE associated with the various sedentary and physical activities, which may favour body weight regain in the less active POb subjects.
\end{abstract}

\section{body composition / basal metabolic rate / physical activity / thermoregulation}

\section{INTRODUCTION}

The prevalence of overweight and obesity has been increasing dramatically in indus- trialised and many developing countries during the last decades [1]. The trends particularly affect children and adolescents [24] who are then at risk of developing a

\footnotetext{
* Corresponding author: vermorel@ clermont.inra.fr
} 
number of medical morbidities [5]. Obesity generally arises from a mismatch between energy intake and energy expenditure (EE). The imbalance results from both a progressive reduction in physical activity, mainly in adolescents $[6,7]$, and an increase in energy intake $[8,9]$. Therefore, EE is a major determinant of energy balance and body composition. Knowledge of its contributing factors enables a better understanding of some drifts in body weight (BW) and body composition, as well as in blood metabolic and hormonal profiles, and offers possibilities to correct the drifts.

According to a usual scheme in human nutrition, daily EE (DEE) can be distributed between basal metabolic rate (BMR) extrapolated to $24 \mathrm{~h}$, and the increases in EE associated with thermoregulation, alimentation (thermic effect of food, TEF), and physical activity, although these factors are interdependent. In addition, for practical purposes, the increase in EE associated with physical activities must be partitioned between sedentary (seated) activities and real physical activities. The objectives of this paper were (1) to review the variation factors of the main components of DEE, and (2) the inter-individual variability in basal metabolic rate, physical activity EE, and DEE in non-obese $(\mathrm{NOb})$, obese $(\mathrm{Ob})$, and post-obese (POb) children and adolescents.

\section{MAIN COMPONENTS OF ENERGY EXPENDITURE IN NON-OBESE CHILDREN AND ADOLESCENTS}

\subsection{Basal metabolic rate}

BMR is a major determinant of DEE since it contributes, on average, $60 \%$ to DEE. However, it ranges from $45-50 \%$ in very active subjects to about $70 \%$ in sedentary subjects. BMR can be considered as the sum of the EE of tissues and organs at fast and rest and in thermoneutral conditions. Therefore, it depends on mass and metabolic rate $\left(\mathrm{EE} \cdot \mathrm{g}\right.$ tissue $\left.{ }^{-1} \cdot \mathrm{min}^{-1}\right)$ of tissues and organs, and broadly speaking from body composition as expressed as fat-free mass (FFM) and fat mass (FM), sex, age, physical and nutritional status.

The major components of cellular metabolic rate are nucleic acid and protein turnover (20-25\% [10], phospholipid and tryglicerides turnover (5\%) [11], active transports $\left(\mathrm{NA}^{+}, \mathrm{K}^{+}, 20-30 \%\right.$; $\mathrm{Ca}^{2+}, 5 \%$, [12-14] and substrate cycles (10\%, on average) [15]), as well as anabolic pathways. The intensity of these phenomena depends on metabolic functions of tissues and organs, and is subject to hormonal regulation (catecholamines, thyroid hormones $[16,17]$, insulin, glucocorticoids, growth hormone [18], IGF1, testosterone [19], etc.), and nutritional regulation, especially energy intake [20,21]. Therefore, the metabolic rate of tissues and organs is highly variable. For instance, it is about $10,15,20$, 35 , and 35 times higher in the digestive tract, liver, brain, heart, and kidney than in resting muscle, whereas it is only about $1 / 3$ in white adipose tissues [22]. Consequently, while organs account for about $7 \%$ of BW, they contribute about $60 \%$ to BMR, whereas skeletal tissues and adipose tissues account for $35-40 \%$ and $15-30 \%$ of BW and contribute only $18-22 \%$ and $3-4 \%$ to BMR, respectively [23]. In addition, organ mass increases relatively less than skeleton and muscle mass during childhood and adolescence. Consequently, the contribution of organs to BW decreases from about $10 \%$ to $6 \%$ between 10 and 20 years of age [22].

The main significant determinant of BMR is $\operatorname{FFM}\left(R^{2}=0.65-0.80[24,25]\right)$, whereas FM is significant only in obese subjects $\left(R^{2}<0.04,[24,26]\right)$. Sex is also a significant determinant of BMR $\left(0.02<R^{2}<0.04\right.$, [24]): after adjustment for body composition, BMR is significantly higher in boys than in girls, by $3 \%$ and $6 \%$ in prepubertal and pubertal subjects, respectively [24, 27, 28], because of (1) higher proportions of skeletal glycolytic fibres [29], and higher $\mathrm{Na}^{+}-\mathrm{K}^{+}$ATPase activity [30], and (2) changes in hormonal status [19]. 
BMR is higher in trained than in untrained adolescents, because of their higher FFM [31]. However, after adjustment for body composition BMR is not significantly different between trained and untrained subjects [32-34].

Finally genetic factors influence BMR, probably through differences in organ mass and metabolic rate, and hormonal status [35], since the residual standard deviation of BMR adjusted for the previous determinants averages $7 \%$ [36].

\subsection{Growth}

During the growth period, energy is stored in the body as protein and lipids (23.4 and $39.7 \mathrm{~kJ} \cdot \mathrm{g}^{-1}$, respectively). Body weight gain averages $10 \mathrm{~g} \cdot \mathrm{d}^{-1}$ before the onset of puberty, and increases to $25-30 \mathrm{~g} \cdot \mathrm{d}^{-1}$ at peak of growth (at 12 years of age in girls and 14 years in boys) while lipid gain is very low in boys. Consequently, energy stored in the body ranges from 85 to $125 \mathrm{~kJ} \cdot \mathrm{d}^{-1}$ in boys between 10 and 15 years of age, then decrease to less than $40 \mathrm{~kJ} \cdot \mathrm{d}^{-1}$ in boys. On the contrary, the fat mass increases continuously in girls, and energy stored in the body increases from $125-165 \mathrm{~kJ} \cdot \mathrm{d}^{-1}$ in prepubertal girls to $290-335 \mathrm{~kJ} \cdot \mathrm{d}^{-1}$ at peak of growth, then declines rapidly. Consequently, assuming a 50-70\% efficiency of energy utilisation for growth, depending on the proportion of energy stored as lipids, growth would contribute 2 to $4 \%$ of daily energy requirements in adolescents [37].

\subsection{Thermic effect of food (TEF)}

TEF includes increases in EE during ingestion and digestion of food, and metabolism of nutrients instead of body reserves. It averages $12 \%$ of energy intake (EI), which is generally close to DEE, over a 24-hmeasurement period [38]. It is lower for lipids and carbohydrates (3 and 5\% of EI, respectively, over 3-4 h periods) than for protein $(20-25 \%)$ because of the energy cost of urea synthesis, the likely effect on protein turnover, and the stimulating effect on the sympathetic nervous system $[39,40]$. However, the small variations in TEF with usual diets hardly affect DEE of NOb subjects.

\subsection{Thermoregulation}

The increase in EE of subjects exposed to cold depends on the extent and duration of cold exposure and clothing and on their current EE which is closely linked to physical activity intensity. In developed countries, the effects of cold are minimised by adjustment of clothing, housing and heating [41]. However, people can be exposed to cold during short periods of time because of inadequate clothing or rapid changes in environmental conditions. In mild cold conditions, heat loss is decreased by peripheral vasoconstriction, whereas EE is first increased by spontaneous alteration of activity pattern and increases in muscular tone and metabolic rate, resulting in 5-7\% increases in resting $\mathrm{EE}$ in normally clothed women exposed to $22{ }^{\circ} \mathrm{C}$ compared to $28^{\circ} \mathrm{C}$ [42].

In more severe environmental conditions, especially with wind and humidity, the EE of naked or lightly clothed resting people could be increased up to 5 times, on average, by shivering [43, 44]. However, the shivering peak of EE corresponds to only $42 \pm 5 \%$ of $\mathrm{VO}_{2} \max$, that is to the increase in EE during physical activities such as walking at $6 \mathrm{~km} \cdot \mathrm{h}^{-1}$, sport training or hard manual work.

A mathematical model for predicting human thermal and regulatory responses in cold, cool, neutral, warm, and hot environments has been developed from the results of 26 independent experiments. The model was validated using experimental data obtained from 90 exposures covering a range of steady and transient ambient temperatures and exercise intensities [45]. This model enabled the prediction of heat loss and EE of an average person (body weight: $73.5 \mathrm{~kg}$; FM content: $14 \%$, BMR: $5.23 \mathrm{~kJ} \cdot \mathrm{min}^{-1}$ ) depending on environmental temperature (Ta), air velocity, and clothing ensemble. 
After 30 min exposure to Ta ranging from 20 to $0{ }^{\circ} \mathrm{C}$ in calm air $\left(0.1 \mathrm{~m} \cdot \mathrm{s}^{-1}\right)$, heat loss increases from 9 to 15,17 , and $22 \mathrm{~kJ} \cdot \mathrm{min}^{-1}$ in the average person wearing an appropriate casual clothing ensemble, a soccer dress plus a tracksuit, or only a soccer dress, respectively. The effects of Ta and clothing on heat loss are much more important with an air velocity of $5 \mathrm{~m} \cdot \mathrm{s}^{-1}\left(20,24\right.$, and $35 \mathrm{~kJ} \cdot \mathrm{min}^{-1}$ at $0{ }^{\circ} \mathrm{C}$, respectively). The physical activity ratios $(\mathrm{PAR}=\mathrm{EE} / \mathrm{BMR})$ necessary to increase $\mathrm{EE}$ for balancing heat loss, and the corresponding usual physical activities were calculated. The PAR average 2.8, 3.2, and 4.2, respectively, at $0{ }^{\circ} \mathrm{C}$ and calm air, and 3.9, 4.7, and 6.7, respectively, at $0{ }^{\circ} \mathrm{C}$ and $5 \mathrm{~m} \cdot \mathrm{s}^{-1}$ air velocity. Such PAR correspond to walking at various speeds $(3 \leq \mathrm{PAR} \leq 4.5)$ or physical training $(5 \leq \mathrm{PAR} \leq 7)$, and can easily be reached by moderately active adolescents. In sedentary subjects the energy deficit is only partially compensated for by non-shivering and shivering thermogenesis.

Thus, in industrialised countries with temperate climatic conditions, the effects of thermoregulation on EE are usually negligible for most children and adolescents who spend most of the time indoors, except in the winter during recreations, and at the beginning of the physical education lessons or training sessions performed outdoors if children and adolescents are not adequately clothed.

\subsection{Physical activity EE in non-obese children and adolescents}

Physical activity EE (AEE) is a major component of DEE. The latter has been determined in children and adolescents over a period of 10-15 days using the doubly labelled water (DLW) method [46-50] or the heart-rate recording method $[31,51,52]$. AEE was estimated as DEE minus BMR $\times$ 1440 or DEE minus TEF and BMR $\times 1440$, assuming that TEF averaged 0.1 DEE [46, 53]. AEE averaged $33-39 \%$ and $42-47 \%$ of DEE in 15-y-old girls and boys, respectively [46, 47, 50-52, 54]. However, AEE overestimates the EE associated with real physical activities because it includes increases in EE above BMR during sedentary activities [7].

EE associated with real physical activity was assessed in $110 \mathrm{NOb}$ children and adolescents aged 10-18 years in standardised and in free-living conditions. EE was determined by whole-body indirect calorimetry with a standardised activity programme simulating their usual activities, to determine changes in EE with sex, age or pubertal stage and body composition $[36,55,56]$. EE and heart rate (HR) were continuously recorded. Mean EE $\left(\mathrm{kJ} \cdot \mathrm{min}^{-1}\right)$ during sleep, various sedentary activities, walking at several speeds and recovery periods were determined. In addition, individual polynomial relationships between heart rate (HR) and EE recorded over a 24-h-period were computed. Then, $\mathrm{DEE}$ and the circadian variations of $\mathrm{EE}$ were determined in free-living conditions during 5 or 7 consecutive days using the HR recording method and an activity diary. EE associated with light physical activities (slow walking, shopping, recreation, playing quietly), moderate physical activities (fast walking, recreation sport, dancing) and team sport (physical education lessons, training and competition) averaged 8.5, 7.2, and $8.3 \%$ of DEE, respectively. They were lower in girls than in boys, and decreased between 12.5 and 15.0 years of age [52].

In addition, the mean energy EE of adolescents during 19 usual activities were assessed and are expressed as multiples of sleeping or basal metabolic rate (physical activity ratio, PAR). The PARs did not vary significantly with sex and age between 12 and 18 years of age. They averaged 1.3 and 1.4 during TV watching in the lying and sitting position, respectively; $1.5-1.8$ during sedentary activities including meals; 2.5 during light activities; 3.5 during moderate activities, and 4-6 during sports [52] (Fig. 1). The PAR of training and competition in adolescent athletes were also assessed for several sports. They averaged 5-7 at light 


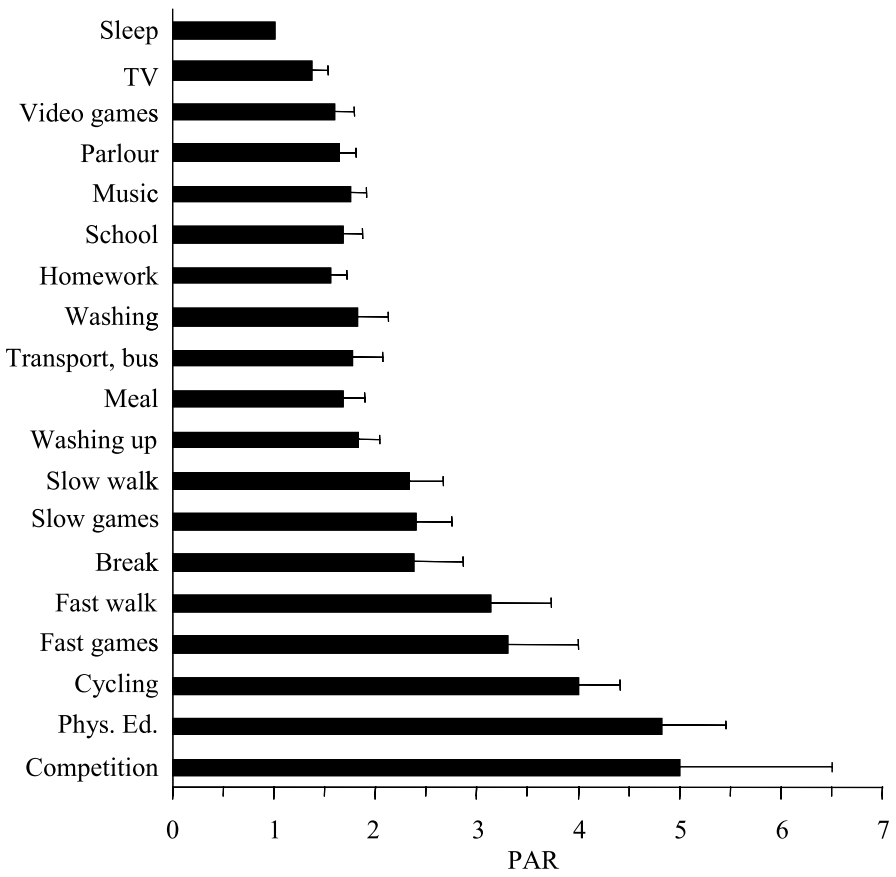

Figure 1. Energy cost (physical activity ratio, PAR) of activities in non-obese adolescents in freeliving conditions (mean and standard deviation).

intensity, 6-10 at moderate intensity, and 9-15 at high intensity [57] (Fig. 2).

\subsection{Variability of energy expenditure in non-obese adolescents}

Changes in the EE of boys and girls (1316 subjects per group) with age (10-18 y) were determined both in standardised and in free-living conditions $[52,55,56]$. With the same activity programme in the calorimeters, sleeping and daily EE were 9.8, 23.0 , and $34.1 \%$ higher in boys than in girls at $12.5,15.0$ and 18 years of age, respectively $(P<0.001)$, but not at 10 years of age. They increased with age, and interestingly plateaued at 13 and 16 years of age in boys and girls, respectively, and tended to decrease in 18-year-old girls (Fig. 3), in spite of significant increases in BW and FFM [52].

In free-living conditions, changes in DEE with age and sex were similar to changes in standardised conditions (Fig. 4). In addition, the inter-individual variability of DEE in each age-class was high since the standard deviation and the range averaged 1.7 and $5.8 \mathrm{MJ} \cdot \mathrm{d}^{-1}$, respectively. The inter-individual variability of DEE resulted not only from differences in BW and FFM, but mainly from the variability in the energy cost of the various activities and in physical activity EE. The coefficients of variation of PAR averaged $11 \%$ for sedentary activities, $16 \%$ for washing, dressing, and travelling by bus, and $20 \%$ for physical activities including training and competition. The time devoted to moderate and sport activities ranged from 40 to $160 \mathrm{~min} \cdot \mathrm{d}^{-1}$ on average, over a week in boys and girls both at 12.5 and 15.0 years of age. The intensity of these activities also differed among subjects so that the increases in EE above sedentary activity EE ranged from 0.16 to $2.70 \mathrm{MJ} \cdot \mathrm{d}^{-1}$ (Fig. 5). Consequently, the physical activity 


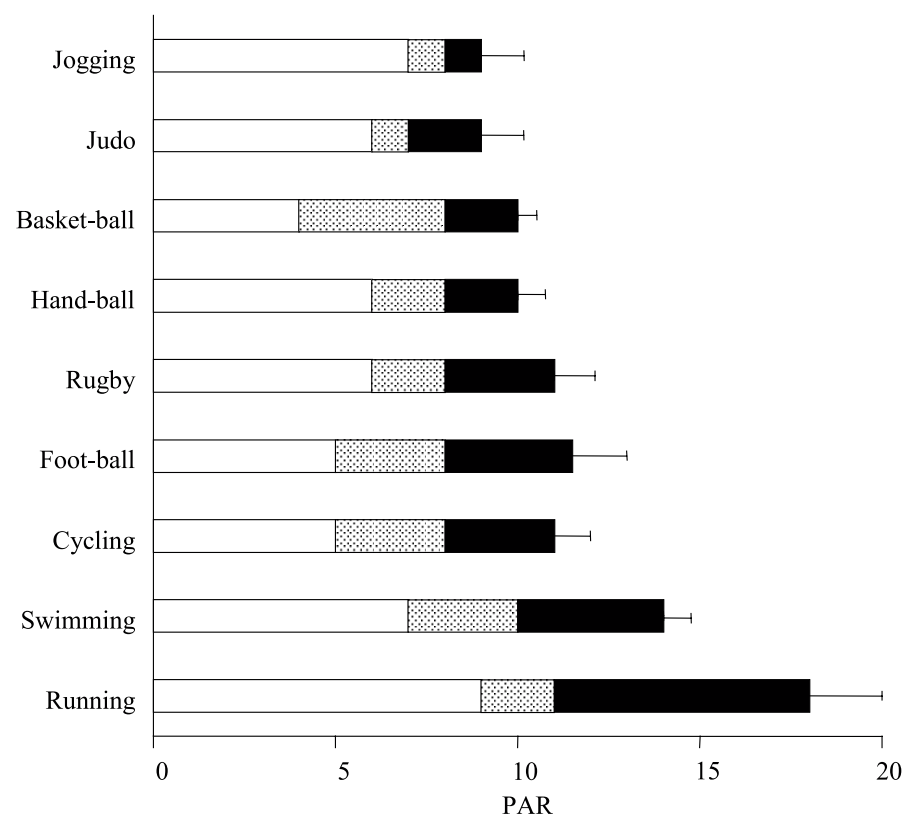

Figure 2. Energy cost (physical activity ratio, PAR) of sport activities at light ( $\square$ ), moderate (圆), and high intensity ( $\mathbf{\square})$ (mean and standard deviation).

level $(\mathrm{PAL}=\mathrm{DEE} / \mathrm{BMR})$ ranged from 1.4 to 2.0 , and averaged 1.75 in boys between 12 and 18 years of age, and in the 12.5-yearold girls in agreement with the literature $[43,51,58]$. However, PAL was lower (1.65) in the 15-and 18-y-old girls in agreement with the literature [51]. These results agreed with the changes in activity patterns of girls after puberty [59].

However, EE associated with physical activity is higher in active adolescents. PAL averaged 1.93 and 1.89 in 17 -y-old athletes, boys and girls, respectively, who devoted, on average, $0.85 \mathrm{~h} \cdot \mathrm{d}^{-1}$ to moderate intensity physical activities, and $1.70 \mathrm{~h} \cdot \mathrm{d}^{-1}$ to sport activities [56]. PAL was still higher (2.23 in boys and 1.98 in girls) in very active Swedish adolescents who practiced, on average, 1.57 and $1.36 \mathrm{~h} \cdot \mathrm{d}^{-1}$ of sport activities, and $2.15 \mathrm{~h} \cdot \mathrm{d}^{-1}$ of moderate intensity activities such as walking or riding a bicycle to school, 2.09 and $2.75 \mathrm{~h} \cdot \mathrm{d}^{-1}$ of light intensity physical activities such as walking indoors [50].

\section{ENERGY EXPENDITURE IN OBESE ADOLESCENTS}

Because of their higher body weight and greater FFM, obese children and adolescents have higher DEE, BMR and AEE than do non-obese subjects [46, 60, 61]. However, obese children are known to spend less time in physical activities and more time in sedentary activities than do their age-matched counterparts [60, 62-64]. This observation raises the question of metabolic rate and energy cost of activities in obese children and adolescents.

DEE and EE associated with usual sedentary and physical activities were assessed in $60 \mathrm{NOb}$ adolescents ( 23 boys and 27 girls), and $27 \mathrm{Ob}$ adolescents (13 boys and 14 girls) of similar age $(14.0 \pm 0.3 \mathrm{y})$ and height $(163.4 \pm 2.2 \mathrm{~cm})$ [7]. BW, BMI, FFM and FM were significantly higher in $\mathrm{Ob}$ than in NOb subjects: 92.1 vs. $49.7 \mathrm{~kg} ; 34.1$ vs. $18.8 \mathrm{~kg} \cdot \mathrm{m}^{-2}, 52.4 \mathrm{vs} .39 .9 \mathrm{~kg}$, and $43.1 \mathrm{vs}$. 

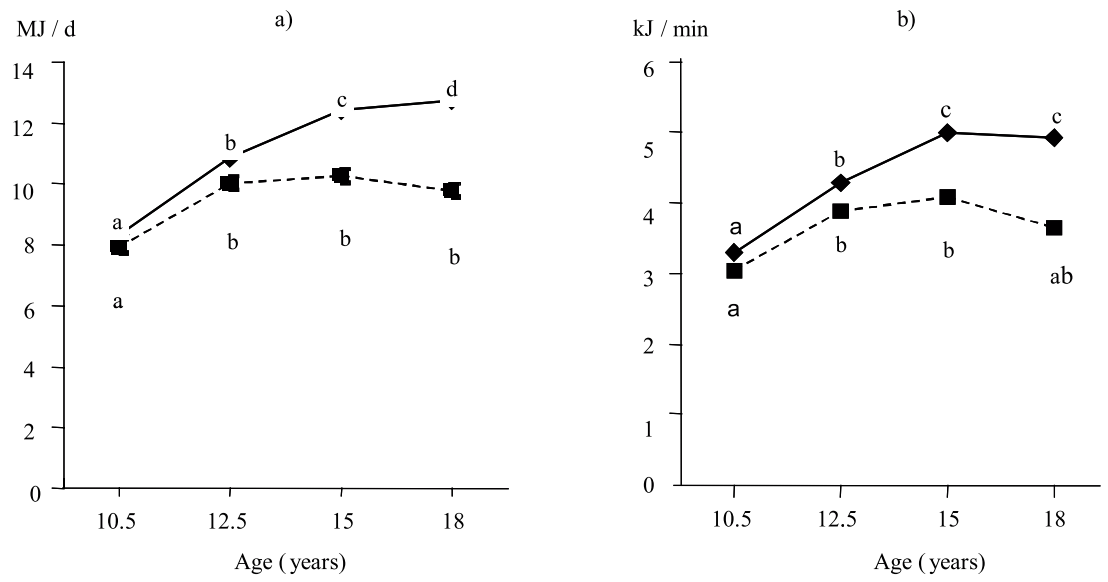

Figure 3. Changes in daily energy expenditure (a) and sleeping energy expenditure (b) in boys $(-)$ and girls (- - ) with a standardised activity programme in the whole-body calorimeters, between 10 and 18 years of age (values with different superscripts are significantly different between age groups and genders).

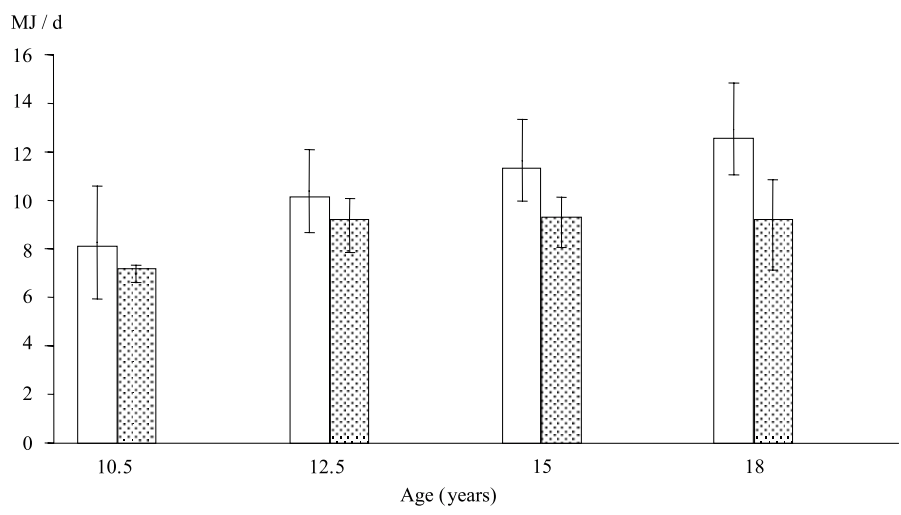

Figure 4. Changes and variability in daily energy expenditure in boys ( $\square$ ) and girls (ㄱ) between 10 and 18 years of age in free-living conditions (mean and standard deviation)

$19.7 \mathrm{~kg}$, respectively. Excess weight was composed of $27 \%$ FFM and $73 \%$ FM, on average.

Sleeping EE and sedentary activities EE, as determined in standardised conditions during a 36 h-stay in two whole-body calorimeters, were $19 \%$ higher in $\mathrm{Ob}$ than in NOb subjects ( 2.92 vs. 2.46 , and 6.75 vs. $5.67 \mathrm{MJ} \cdot \mathrm{d}^{-1}$, respectively). However, after adjustment for body composition, sleeping EE and sedentary activities EE were not sig- nificantly different between $\mathrm{Ob}$ and $\mathrm{NOb}$ subjects. These results agreed with previous results showing that BMR, sleeping and sedentary EE are closely correlated to FFM $[46,53]$. In addition, these results suggest that tissue and organ metabolic rates are not significantly different between $\mathrm{Ob}$ and NOb subjects.

TEF could not be determined accurately in this study, but previous studies showed that TEF is about $25 \%$ lower in $\mathrm{Ob}$ than in 


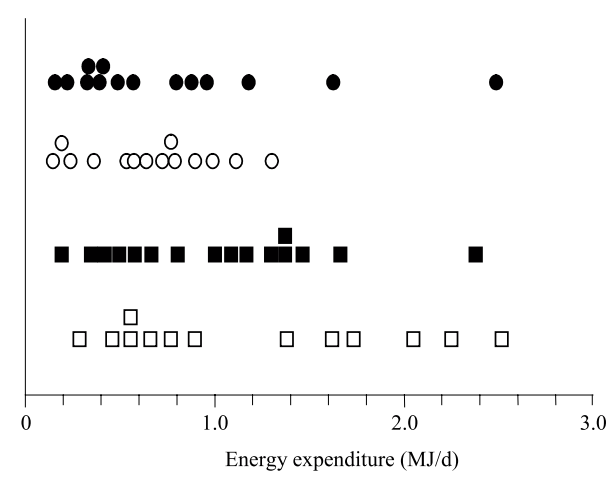

Figure 5. Inter-individual variability in the increase in energy expenditure due to physical activities in boys aged 12 years $(\square)$ or 15 years $(\square)$, and in girls aged 12 years $(\mathrm{O})$ or 15 years $\bullet$ in free-living conditions (mean values over a week).

NOb children [65, 66]. However, the corresponding decrease in DEE was small $(1.5 \%)$.

The metabolic response to cold in obese adult subjects is inversely related to body fatness but may vary with the type of obesity [67]. The increase in EE of normally clothed obese women exposed to a mild cold $\left(23.3{ }^{\circ} \mathrm{C}\right)$ was lower than that of nonobese women [68], whereas other authors did not observe significant differences [41]. At low environmental temperature, skin temperature decreases less in obese than in lean subjects [69] partly because of a higher peripheral thermal insulation. In addition, fatter subjects respond to cold air exposure with a later onset and a lower intensity of shivering than do lean subjects [43]. Consequently, subjects with higher body weight and greater body fatness can face more severe cold and for longer periods than can lean subjects [44].

EE during walking at the same speeds on a treadmill in the whole-body calorimeters was $81 \%$ higher in $\mathrm{Ob}$ than in NOb subjects $(3.8$ vs. $2.1 \mathrm{MJ})(P<0.001)$. After adjustment for BW, it was still $25 \%$ higher in $\mathrm{Ob}$ than in NOb subjects $(P<0.001)$, probably because of greater difficulty of walking in

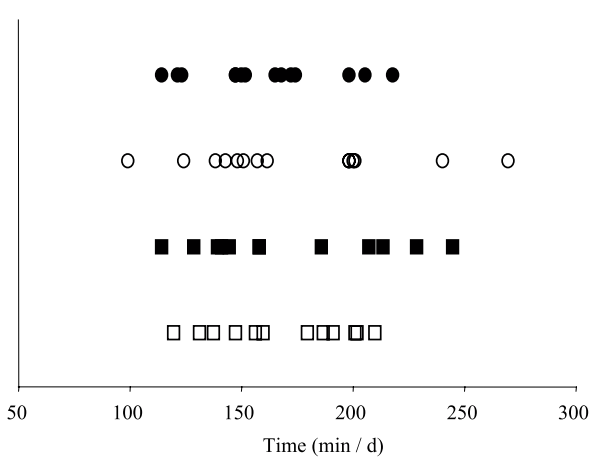

Figure 6. Inter-individual variability in time devoted to physical activities in obese $(\square)$ or post-obese ( $\square$ ) boys, and in obese (O) or postobese $(\bullet)$ girls in free living conditions.

severely obese subjects [7]. In free-living conditions, sleeping EE, sedentary activities EE and DEE were 16\%, $42 \%$ and $22 \%$ higher, respectively, in $\mathrm{Ob}$ than in NOb adolescents $(P<0.001)$, whereas EE associated with physical activities were not significantly different. After adjustment for body composition, sleeping EE, sedentary activities EE and DEE were not significantly different between $\mathrm{Ob}$ and $\mathrm{NOb}$ subjects. On the contrary, EE associated with physical activities were $61 \%$ lower $\left(1.4\right.$ vs. $\left.3.6 \mathrm{MJ} \cdot \mathrm{d}^{-1}\right)$ in $\mathrm{Ob}$ adolescents $(P<0.001)$ in spite of the higher energy cost of physical activities. In fact, the $\mathrm{Ob}$ adolescents spent $47 \mathrm{~min} \cdot \mathrm{d}^{-1}$ more at light physical activities (slow walking, housework, etc.) and $53 \mathrm{~min} \cdot \mathrm{d}^{-1}$ less at moderate physical activities (walking at a normal speed, recreational activities, etc.) than the NOb subjects. Time devoted to physical activities was equivalent to 69 and $122 \mathrm{~min} \cdot \mathrm{d}^{-1}$ walking at $5 \mathrm{~km} \cdot \mathrm{h}^{-1}$ in $\mathrm{Ob}$ and NOb adolescents, respectively [7].

The inter-individual variability in $\mathrm{EE}$ was also high and gender dependent in obese adolescents. After adjustment for differences in FFM, it averaged $\pm 10.1 \%$ in boys and $\pm 12.4 \%$ in girls for EE during sedentary activities in standardised conditions (whole-body calorimeter). Similarly, after adjustment for BW, the inter-individual variability in EE during walking at $5 \mathrm{~km} \cdot \mathrm{h}^{-1}$ on 


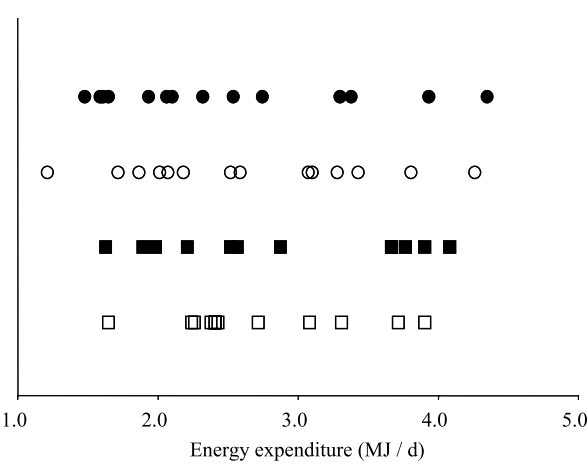

Figure 7. Inter-individual variability in energy expenditure associated with physical activities in obese $(\square)$ or post-obese $(\square)$ boys, and in obese $(\mathrm{O})$ or post-obese $(\bullet)$ girls in free-living conditions (mean values over a week).

a treadmill was $\pm 21.3 \%$ in boys and $\pm 12.9 \%$ in girls [7], which suggests differences in walking efficiency.

In free-living conditions the time devoted by obese adolescents to physical activities ranged from 99 to $270 \mathrm{~min} \cdot \mathrm{d}^{-1}$ (mean: 171

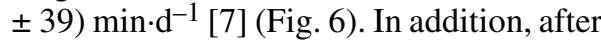
adjustment for $\mathrm{BW}$ the inter-individual variability in $\mathrm{EE}\left(\mathrm{kJ} \cdot \mathrm{min}^{-1}\right)$ during physical activities averaged $\pm 11.9 \%$ depending on the respective contribution of very light, light and moderate intensity activities. Consequently, after adjustment for BW, the inter-individual variability in EE associated with physical activities was $24.7 \%$ in obese boys and $32.7 \%$ in obese girls (Fig. 7). These results support the opinion that the energy imbalance responsible for overweight and obesity may result either from low physical activity and a small excess of energy intake, or from adequate physical activity but a large excess of energy intake.

\section{ENERGY EXPENDITURE IN POST-OBESE ADOLESCENTS}

Energy restriction, a common treatment of obesity, is usually effective in achieving short-term BW and FM loss, but it is asso- ciated with FFM reduction, which could explain the usual decrease in BMR $[17,70$, 71], and a further BW regain. On the contrary, TEF is significantly higher in $\mathrm{POb}$ than in $\mathrm{Ob}$ children, and not significantly different between $\mathrm{POb}$ and $\mathrm{NOb}$ children [72]. However, significant decreases in BW and FM, without significant reductions in FFM and BMR, have been reported in children when physical activity is associated with a hypocaloric diet [73]. Thus, a combination of energy restriction and regular physical activity may provide a fruitful strategy to preserve FFM and maintain DEE during a weight-reduction program.

$\mathrm{Ob}$ adolescents in a specialised institution followed a 9-month weight-reduction programme including moderate energy restriction (energy intake 15 to $20 \%$ less than the initial DEE), dietetic education, regular physical activity, and progressive physical training [74]. BW decreased, on average, by 18.0 and $15.8 \mathrm{~kg}$, and FM by 18.0 and $12.5 \mathrm{~kg}$ in boys and girls, respectively, whereas FFM did not vary significantly in boys, mainly because of height gain, but decreased by $3.3 \mathrm{~kg}$ in girls $(P<0.001)$. Physical capacities and cardio-vascular fitness were also significantly improved [74].

In standardised conditions (whole-body calorimetry) BMR, sleeping EE and sedentary activity EE were 8.3, 14.0 and $14.0 \%$ lower, respectively, at the end than at the beginning of the weight-reduction period $(P<0.001)$. The differences were still significant $(-6.8,-12.6$, and $-11.7 \%$, respectively, $P<0.001$ ) after adjustment for body composition [74]. This phenomenon could result from reductions in organ (stomach, intestines liver, pancreas, kidneys, etc.) mass and metabolic rate due to energy restriction, as shown in farm animals [75-77]. In addition, EE during walking at the same speeds decreased significantly $(-23 \%)$ even after adjustment for BW $(-17.6 \%, P=0.004)$. This phenomenon may result from easier walking and improved work efficiency after weight loss [78, 79]. Consequently, with the same activity programme, DEE 
was significantly lower after than before the weight-reduction programme, both in absolute value $(-16.4 \%, P<0.001)$ and after adjustment for FFM $(-14.0 \%, P<0.001)$. The decrease in metabolic rate and EE for all types of activities may favour BW regain in less active adolescents.

In free-living conditions, DEE, sleeping EE and sedentary EE were $8 \%, 14 \%$ and $22 \%$ lower than before the weight-reduction programme, respectively $(P<0.001)$. On the contrary, EE associated with real physical activities $\left(\mathrm{kJ} \cdot \mathrm{min}^{-1}\right.$ and $\left.\mathrm{kJ} \cdot \mathrm{d}^{-1}\right)$ were not significantly different before and after the weight reduction programme in spite of BW loss, indicating an increase in type or intensity of physical activities. In fact, time and EE corresponding to moderate physical activities increased from 21 to $49 \mathrm{~min} \cdot \mathrm{d}^{-1}$ $(P<0.03)$, and from 0.13 to $0.49 \mathrm{MJ} \cdot \mathrm{d}^{-1}$ $(P<0.025)$, respectively, at the expense of sedentary activities during the weight reduction programme [80].

The inter-individual variability in EE $\left(\mathrm{kJ} \cdot \mathrm{min}^{-1}\right)$ remained high after the weightreduction programme. After adjustment for FFM it averaged $\pm 10.5 \%$ in boys, but it was reduced to $\pm 6.9 \%$ in girls during sedentary activities in standardised conditions. The phenomenon was similar for EE during walking at $5 \mathrm{~km} \cdot \mathrm{h}^{-1}$ on a treadmill: the interindividual variability in EE averaged $\pm 21.6 \%$ in boys and $\pm 9.9 \%$ in girls [74]. In free-living conditions, the inter-individual variability in EE and time devoted to physical activities increased in boys, but decreased in girls, mainly due to great changes in 3 and 2 subjects in each group [80] (Figs. 6 and 7).

Thus, in spite of life-style education, physical training and regular physical activity, body weight loss and improvement of physical capacities during a 9-month-weightreduction programme, the inter-individual variability in physical activity (time and intensity) remains high among post-obese adolescents, which may favour BW regain in the less active subjects.

\section{CONCLUSION}

Body composition, especially FFM, physical activity (nature, duration and intensity) and, to a lesser extent, sex are the major variation factors of $\mathrm{DEE}$ in $\mathrm{NOb}, \mathrm{Ob}$ and $\mathrm{POb}$ adolescents, whereas FM, growth, TEF and thermoregulation are generally of marginal importance. Nevertheless, after adjustment for the main variation factors, the inter-individual variability in BMR, sleeping $E E$, and sedentary activity EE remains high, which suggests that other factors of genetic, hormonal or nervous origin affect the tissue metabolic rate of individuals. In addition, the inter-individual variability in DEE and physical activity EE among NOb adolescents in free-living conditions is considerable mainly because of the very little time devoted to moderate and medium intensity physical activities by many adolescents. This suggest that a sedentary lifestyle may have played a major role in the increase in the prevalence of overweight and obesity in children and adolescents during the last decades.

Multidisciplinary weight-reduction programmes including energy restriction, physical training and regular physical activity result in great FM loss, maintenance of FFM, improvement of physical capacities, and increases in time devoted to moderate physical activities in most subjects. However, the reduction in metabolic rate and in EE associated with sleep, sedentary and physical activities favours BW regain in the less active $\mathrm{NOb}$ subjects. Therefore, moderate and high intensity physical activities have to be performed regularly after the end of the weight-reduction programme to preserve its beneficial effects.

\section{ACKNOWLEDGMENTS}

The authors are grateful to Dr D Fiala (Institute of Energy and Sustainable Development, IESD, De Montfort University, Leicester, UK) for computing the components of heat loss and heat production in the various environmental conditions, and Dr R Taylor (INRA, ClermontFerrand-Theix, France) for revising the English. 


\section{REFERENCES}

[1] Seidell JC. Obesity: a growing problem. Acta Paediatr 1999, 88 (Suppl): 46-50.

[2] Troiano RP, Flegal KM. Overweight prevalence among youth in the United States: why so many different numbers? Int J Obes Relat Metab Disord 1999, 23 (Suppl 2): S22-S27.

[3] Lazarus R, Wake M, Hesketh K, Waters E. Change in body mass index in Australian primary school children 1985-1997. Int J Obes Relat Metab Disord 2000, 24: 679-684.

[4] Lobstein T, Frelut ML. Prevalence of overweight among children in Europe. Obes Rev 2003, 4: 195-200.

[5] Bray GA. Overweight, mortality, and morbidity. In: Bouchard C (Ed), Physical activity and obesity, Human Kinetics, Luisiana, 2000, p 31-53.

[6] Ekelund U, Aman J, Yngve A, Renman C, Westerterp K, Sjostrom M. Physical activity but not energy expenditure is reduced in obese adolescents: a case-control study. Am J Clin Nutr 2002, 76: 935-941.

[7] Lazzer S, Boirie Y, Bitar A, Montaurier C, Vernet J, Meyer M, Vermorel M. Assessment of energy expenditure associated with physical activities in free-living obese and nonobese adolescents. Am J Clin Nutr 2003, 78 : 471-479.

[8] Livingstone B. Epidemiology of childhood obesity in Europe. Eur J Pediatr 2000, 159 (Suppl 1): S14-S34.

[9] Birch LL, Fisher JO. Development of eating behaviors among children and adolescents. Pediatrics 1998, 101: 539-549.

[10] Schutz Y, Rueda-Maza CM, Zaffanello M, Maffeis C. Whole-body protein turnover and resting energy expenditure in obese, prepubertal children. Am J Clin Nutr 1999, 69: $857-$ 862.

[11] Bahr R, Hansson P, Sejersted OM. Triglyceride/fatty acid cycling is increased after exercise. Metabolism 1990, 39: 993-999.

[12] Hawkins M, Whittaker J, Wales JK, Swaminathan R. Erythrocyte sodium content, sodium transport, ouabain binding capacity and $\mathrm{Na}^{+}, \mathrm{K}^{+}$-ATPase activity in lean and obese subjects. Horm Metab Res 1984, 16: 282-285.

[13] Martin LF, Dean WL, Flint LM Jr, Suarez CP, Ratcliffe DJ, Fry DE. Erythrocyte sodiumpotassium-stimulated adenosine triphosphatase activity is not related to obesity. J Surg Res 1983, 34: 473-478.

[14] Flodmark CE, Henningsen NC, Sveger T. Red cell sodium-potassium adenosine triphosphatase sites and intracellular sodium increased in obese school children. Miner Electrolyte Metab 1992, 18: 6-8.

[15] Hirsch J, Leibel RL, Edens NK. Cellular corollaries of energy expenditure. In: Kinney MJ, Tucker HN (Eds). Energy metabolism: Tissue determinants and cellular corollaries. Raven Press, New York, 1992, p 525-532.

[16] Reinehr T, Andler W. Thyroid hormones before and after weight loss in obesity. Arch Dis Child 2002, 87: 320-323.

[17] Kiortsis DN, Durack I, Turpin G. Effects of a low-calorie diet on resting metabolic rate and serum tri-iodothyronine levels in obese children. Eur J Pediatr 1999, 158: 446-450.

[18] Davidson MB. Effect of growth hormone on carbohydrate and lipid metabolism. Endocr Rev 1987, 8: 115-131.

[19] Ferraro R, Lillioja S, Fontvieille AM, Rising R, Bogardus C, Ravussin E. Lower sedentary metabolic rate in women compared with men. J Clin Invest 1992, 90: 780-784.

[20] Goran MI, Calles-Escandon J, Poehlman ET, O'Connell M, Danforth E Jr. Effects of increased energy intake and/or physical activity on energy expenditure in young healthy men. J Appl Physiol 1994, 77: 366-372.

[21] Leibel RL, Rosenbaum M, Hirsch J. Changes in energy expenditure resulting from altered body weight. N Engl J Med 1995, 332: 621628.

[22] Elia M. Organ and Tissue Contribution to Metabolic Rate. In: Kinney MJ, Tucker HN (Eds), Energy metabolism: Tissue determinants and cellular corollaries. Raven Press, New York, 1992, p 61-79.

[23] Gallagher D, Belmonte D, Deurenberg P, Wang Z, Krasnow N, Pi-Sunyer FX, Heymsfield SB. Organ-tissue mass measurement allows modeling of REE and metabolically active tissue mass, Am J Physiol 1998, 275: E249-E258.

[24] Goran MI, Kaskoun M, Johnson R. Determinants of resting energy expenditure in young children. J Pediatr 1994, 125: 362-367.

[25] Rodriguez G, Moreno LA, Sarria A, Pineda I, Fleta J, Perez-Gonzalez JM, Bueno M. Determinants of resting energy expenditure in obese and non-obese children and adolescents. J Physiol Biochem 2002, 58: 9-15. 
[26] DeLany JP, Bray GA, Harsha DW, Volaufova J. Energy expenditure in preadolescent African American and white boys and girls: the Baton Rouge Children's Study. Am J Clin Nutr 2002, 75: 705-713.

[27] Weinsier RL, Schutz Y, Bracco D. Reexamination of the relationship of resting metabolic rate to fat-free mass and to the metabolically active components of fat-free mass in humans. Am J Clin Nutr 1992, 55: 790-794.

[28] Molnar D, Schutz Y. The effect of obesity, age, puberty and gender on resting metabolic rate in children and adolescents. Eur J Pediatr 1997, 156: 376-381.

[29] Simoneau JA, Bouchard C. Human variation in skeletal muscle fiber-type proportion and enzyme activities. Am J Physiol 1989, 257: E567-E572.

[30] Simat BM, Mayrand RR, From AH, Morley JE, Billington C, Fullerton DS, Ahmed K. Is the erythrocyte sodium pump altered in human obesity? J Clin Endocrinol Metab 1983, 56: 925-929.

[31] Ribeyre J, Fellmann N, Vernet J, Delaitre M, Chamoux A, Coudert J, Vermorel M. Components and variations in daily energy expenditure of athletic and non-athletic adolescents in free-living conditions, Br J Nutr 2000, 84: $531-539$.

[32] Treuth MS, Hunter GR, Pichon C, FigueroaColon R, Goran MI. Fitness and energy expenditure after strength training in obese prepubertal girls. Med Sci Sports Exerc 1998, 30: $1130-1136$.

[33] Westerterp KR, Meijer GA, Janssen EM, Saris WH, Ten Hoor F. Long-term effect of physical activity on energy balance and body composition. Br J Nutr 1992, 68: 21-30.

[34] Wilmore JH, Stanforth PR, Hudspeth LA, Gagnon J, Daw EW, Leon AS, Rao DC, Skinner JS, Bouchard C. Alterations in resting metabolic rate as a consequence of $20 \mathrm{wk}$ of endurance training: the HERITAGE Family Study. Am J Clin Nutr 1998, 68: 66-71.

[35] Heymsfield SB, Gallagher D, Wang Z. Body composition modeling: application to exploration of the resting energy expenditure fatfree mass relationship. Ann NY Acad Sci 2000, 904: 290-297.

[36] Bitar A, Fellmann N, Vernet J, Coudert J, Vermorel M. Variations and determinants of energy expenditure as measured by wholebody indirect calorimetry during puberty and adolescence. Am J Clin Nutr 1999, 69: 1209_ 1216
[37] Prentice AM, Lucas A, Vasquez-Velasquez L, Davies PS, Whitehead RG. Are current dietary guidelines for young children a prescription for overfeeding? Lancet 1988, 2: 10661069.

[38] Tataranni PA, Larson DE, Snitker S, Ravussin E. Thermic effect of food in humans: methods and results from use of a respiratory chamber. Am J Clin Nutr 1995, 61: 1013-1019.

[39] Jequier E, Schutz Y. Energy expenditure in obesity and diabetes. Diabetes Metab Rey 1988, 4: 583-593.

[40] Acheson KJ, Jéquier E, Wahren J. Influence of $B$-adrenergic blockade on glucose-induced thermogenesis in man. J Clin Invest 1983, 72: 981-986.

[41] Warwick PM, Busby R. Influence of mild cold on $24 \mathrm{~h}$ energy expenditure in "normally" clothed adults. Br J Nutr 1990, 63: 481-488.

[42] Dauncey MJ. Influence of mild cold on $24 \mathrm{~h}$ energy expenditure, resting metabolism and diet-induced thermogenesis. Br J Nutr 1981, 45: 257-267.

[43] Tikuisis P, Bell DG, Jacobs I. Shivering onset, metabolic response, and convective heat transfer during cold air exposure. J Appl Physiol 1991, 70: 1996-2002.

[44] Eyolfson DA, Tikuisis P, Xu X, Weseen G, Giesbrecht GG. Measurement and prediction of peak shivering intensity in humans. Eur J Appl Physiol 2001, 84: 100-106.

[45] Fiala D, Lomas KJ, Stohrer M. Computer prediction of human thermoregulatory and temperature responses to a wide range of environmental conditions. Int J Biometeorol 2001, 45: $143-159$

[46] Bandini LG, Schoeller DA, Dietz WH Energy expenditure in obese and nonobese adolescents. Pediatr Res 1990, 27: 198-203.

[47] Davies PSW, Livingstone MBE, Prentice AM, Coward WA, Jagger SE, Stewart C, Strain, IJ, Whitehead RG. Total energy expenditure during childhood and adolescence. Proc Nutr Soc 1991, 50: 14A.

[48] Livingstone MBE, Coward WA, White JA, Stewart CM, Kerr MJ. Daily energy expenditure in free-living children: comparison of the heart-rate monitoring with the doubly labeledwater method $\left({ }^{2} \mathrm{H}_{2}{ }^{18} \mathrm{O}\right)$ method. Am J Clin Nutr 1992, 56: 343-352.

[49] Wong WW. Energy expenditure of female adolescents. J Am Coll Nutr 1994, 13: 332337. 
[50] Bratteby LE, Sandhagen B, Fan H, Enghardt $\mathrm{H}$, Samuelson G. Total energy expenditure and physical activity as assessed by the doubly labeled water method in Swedish adolescents in whom energy intake was underestimated by 7-d diet records. Am J Clin Nutr 1998, 67: 905-911.

[51] Ekelund U, Sjostrom M, Yngve A, Nilsson A. Total daily energy expenditure and pattern of physical activity measured by minute-byminute heart rate monitoring in 14-15 year old Swedish adolescents. Eur J Clin Nutr 2000, 54: 195-202.

[52] Vermorel M, Vernet J, Bitar A, Fellmann N, Coudert J. Daily energy expenditure, activity patterns, and energy costs of the various activities in French 12-16-y-old adolescents in free living conditions. Eur J Clin Nutr 2002, 56: 819-829.

[53] DeLany JP, Harsha DW, Kime JC, Kumler J, Melancon L, Bray GA. Energy expenditure in lean and obese prepubertal children. Obes Res 1995, 3 (Suppl 1): 67-72.

[53] DeLany JP, Harsha DW, Kime J, Melancon L, Bray GA. Energy expenditure in lean and obese prepubertal children. Obes Res 1995, 3 (Suppl 1): 67-72.

[54] Bratteby LE, Sandhangen BO, Lötborn M, Samuelson G. Daily energy expenditure and physical activity assessed by an activity diary in 374 randomly selected 15 -year-old adolescents. Eur J Clin Nutr 1997, 51: 592-600.

[55] Bitar A, Vermorel M, Fellmann N, Coudert J. Twenty-four-hour energy expenditure and its components in prepubertal children as determined by whole-body indirect calorimetry and compared with young adults. Am J Clin Nutr 1995, 62: 308-815.

[56] Ribeyre J, Fellmann N, Montaurier C, Delaitre M, Vernet J, Coudert J, Vermorel M. Daily energy expenditure and its main components as measured by whole- body indirect calorimetry in athletic and non-athletic adolescents, Br J Nutr 2000, 83: 355-362.

[57] Vermorel M, Peres G. Énergie. Apports nutritionnels conseillés pour les enfants et adolescents sportifs de haut niveau de performance. TEC \& DOC Lavoisier, Paris, 2004.

[58] Blaak EE, Westerterp KR, Bar-Or O, Wouters LJ, Saris WH. Total energy expenditure and spontaneous activity in relation to training in obese boys. Am J Clin Nutr 1992, 55: $777-$ 782 .

[59] Armstrong N. Young people physical-activity patterns as assessed by heart-rate monitoring. J Sport Sci 1998, 16: S9-S16.
[60] Maffeis C, Zaffanello M, Pinelli L, Schutz Y. Total energy expenditure and patterns of activity in 8-10-year-old obese and non-obese children. J Pediatr Gastroenterol Nutr 1996, 23: 256-261.

[61] Treuth MS, Figueroa-Colon R, Hunter GR, Weinsier RL, Butte NF, Goran MI. Energy expenditure and physical fitness in overweight vs. non-overweight prepubertal girls. Int J Relat Metab Disord 1998, 22: 440-447.

[62] Dietz WH Jr, Gortmaker SL. Do we fatten our children at the television set? Obesity and television viewing in children and adolescents. Pediatrics 1985, 75: 807-812.

[63] Goran MI, Hunter G, Johnson R. Physical activity related energy expenditure and fat mass in young children. Int $\mathrm{J}$ Obes Relat Metab Disord 1997, 21: 171-178.

[64] Maffeis C, Zaffanello M, Schutz Y. Relationship between physical inactivity and adiposity in prepubertal boys. J Pediatr 1997, 131: 288292.

[65] Maffeis C, Schutz Y, Zoccante L, Micciolo R, Pinelli L. Meal-induced thermogenesis in lean and obese prepubertal children. Am J Clin Nutr 1993, 57: 481-485.

[66] Salas-Salvado J, Barenys-Manent M, Recasens Gracia MA, Marti-Henneberg C. Influence of adiposity on the thermic effect of food and exercise in lean and obese adolescents. Int $\mathbf{J}$ Obes Relat Metab Disord 1993, 17: 717-722.

[67] Buskirk ER, Thompson RH, Whedon GD. Metabolic response to cold air in men and women in relation to total body fat content. $\mathrm{J}$ Appl Physiol 1963, 18: 603-612.

[68] Blaza S, Garrow JS. Thermogenic response to temperature, exercise and food stimuli in lean and obese women, studied by $24 \mathrm{~h}$ direct calorimetry. Br J Nutr 1983, 49: 171-180.

[69] Contaldo F, Scalfi L, Coltorti A, Lanzilli A. Reduced cold-induced thermogenesis in familial human obesity. Klin Wochenschr 1986, 64: 177-180.

[70] Zwiauer KF, Mueller T, Widhalm K. Resting metabolic rate in obese children before, during and after weight loss. Int J Obes Relat Metab Disord 1992, 16: 11-16.

[71] Maffeis C, Schutz Y, Pinelli L. Effect of weight loss on resting energy expenditure in obese prepubertal children. Int J Obes Relat Metab Disord 1992, 16: 41-47.

[72] Maffeis C, Schutz Y, Pinelli L. Postprandial thermogenesis in obese children before and 
after weight reduction. Eur J Clin Nutr 1992, 46: 577-583.

[73] Sothern MS, Loftin M, Suskind RM, Udall JN Jr, Blecker U. The impact of significant weight loss on resting energy expenditure in obese youth. J Investig Med 1999, 47: 222-226.

[74] Lazzer S, Boirie Y, Montaurier C, Vernet J, Meyer M, Vermorel M. A weight reduction program preserves fat-free mass but not metabolic rate in obese adolescents. Obes Res 2004, 12: 233-240.

[75] Koong LJ, Nienaber JA, Pekas JC, Yen JT. Effects of plane of nutrition on organ size and fasting heat production in pigs. J Nutr 1982, 112: $1638-1642$.

[76] Ortigues I, Durand D. Adaptation of energy metabolism to undernutrition in ewes. Contribution of portal-drained viscera, liver and hindquarters. Br J Nutr 1995, 73: 209-226.

[77] McBride BW, Milligan LP. Magnitude of ouabain-sensitive respiration in the liver of growing, lactating and starved sheep. $\mathrm{Br} \mathrm{J}$ Nutr 1985, 54: 293-303.

[78] Weigle DS, Brunzell JD. Assessment of energy expenditure in ambulatory reducedobese subjects by the techniques of weight stabilization and exogenous weight replacement. Int J Obes 1990, 14 (Suppl 1): 69-77; discussion $77-81$.

[79] Rosenbaum M, Vandenborne K, Goldsmith R, Simoneau JA, Heymsfield S, Joanisse R, Hirsch J, Murphy E, Matythews D, Segal KR, Leibel RL. Effects of experimental weight perturbation on skeletal muscle work efficiency in human subjects. Am J Physiol Regul Integr Comp Physiol 2003, 285: R183-R192.

[80] Lazzer S, Boirie Y, Poissonnier C, Petit I, Duché P, Taillardat M, Meyer M, Vermorel $M$. Longitudinal changes in activity patterns, physical capacities, energy expenditure, and body composition in severely obese adolescents during a multidisciplinary weightreduction program. Int J Obesity 2005, 29: $37-46$. 